October - 2003

\title{
The Personalized System of Instruction: Review and applications to distance education
}

\author{
Lyle K. Grant and Robert E. Spencer \\ Athabasca University - Canada’s Open University
}

\begin{abstract}
The present paper a) outlines the basic features of the Personalized System of Instruction (PSI); b) provides a brief history of PSI; and c) describes the application of PSI to distance education. Some common misconceptions about PSI are also addressed. PSI is presented as a helpful universally applicable set of instructional practices that are well suited to distance teaching and learning.
\end{abstract}

Keywords: Personalized System of Instruction; distance learning; computer-based instruction; mastery-learning; self-pacing; higher-order objectives; scholarship of teaching; proctors; tutoring

Cracolice and Roth (1996) wrote:

What would you do if you discovered an instructional strategy that raised the scores of your students from the 50th percentile to the 70th percentile? What if that strategy required more work on your part the first time you taught the course? Would it be worth the effort? Such a strategy has been known for more than 25 years, yet it is virtually ignored.

What if students also liked this teaching method more than lectures? What if the strategy meshed well with computer-based learning, online learning, and distance education?

In this article, we outline the basic features of the strategy that Cracolice and Roth (1996) refer to: the Personalized System of Instruction (PSI), which is also known as the Keller Plan. PSI is a non-traditional method of teaching that thousands of instructors have used at colleges and universities since the 1960s. Although PSI is an effective and empirically validated method of instruction, many traditional and distance educators are unfamiliar with the system, mainly because dissemination of the method occurred during the 1970s, before an entire generation of instructors assumed their positions, and before distance learning came into prominence. The purpose of this paper is to present PSI and its history to potential users in the distance education community. In this paper, we describe the basic elements of PSI, provide a brief history of the system, discuss misconceptions about PSI, and discuss how it may be applied to distance learning. 


\section{Background: What is PSI?}

PSI was originally designed as a classroom-based method of instruction with the intention of improving student achievement and, at the same time, replacing the long tradition of punishment in education with the use of positive consequences for learning. PSI has five defining features:

\section{Stress on the Written Word}

In a PSI course, the instructional content is presented in written form rather than via lectures. PSI teachers normally prepare a written study guide that is designed to assist students with learning. The study guide contains study objectives and questions that focus students' attention on important material to be learned, and provide a clear indication of what students are expected to do. The study guide may also include instructor comments used to elucidate difficult points, exercises and practice problems to prepare students for the unit quiz, thought questions to stimulate students' interest in the exploring the subject matter further, and a supplementary reading list. In addition to the study guide, PSI instructors also prepare a course policy statement or student manual (e.g., Grant, 2002a, 2002b) containing an overview of the course, policies for such matters as essay expectations, deadline dates for exams, and instructor tips for good performance. Keller and Sherman (1974) provide detailed information about the written components of a PSI course.

\section{Unit Mastery Requirement}

In a PSI course, content is separated into portions called units. To advance from one unit to the next, students must demonstrate that they have learned the unit's material. In many PSI courses, students demonstrates unit mastery by taking a quiz that requires a minimum score of, for example, 80 percent or 90 percent. Students who fail the first attempt at the quiz are typically given at least two additional attempts to pass the unit by taking a different form of the unit quiz. When the course objectives require some kind of evaluation, other than a paper-and-pencil quiz such as an essay (e.g., McFarland, 1976; Mills, 1978), or demonstration of a physical skill (Cregger and Metzler, 1992), students are also given multiple opportunities to demonstrate mastery. Providing remedial opportunities for students to learn substantially removes the stigma of failure. Remedial opportunities also transform the purpose of grades: grades are not used to rank students relative to each other, but are instead used as incentives to promote achievement.

\section{Student Self-Pacing}

A system of individualized student pacing follows from PSI's use of a unit mastery requirement. Because some students take more time to master individual units, students will thus progress through a PSI course at different rates. Some students finish a PSI course relatively quickly, while others require the total allotted time (e.g., a semester) to finish the course. As such, once a PSI course has begun, students enrolled $n$ the same course, will work on different units of the same course depending on their rate of progress. Unlike the lock-step model of traditional instruction, a self-paced model recognizes and accounts for differences among students in the rate at which they learn the course material and avoids grade penalties for students who require more time to learn. Although PSI can be used within conventional academic time units like semesters, PSI works especially well when an entire institution functions on a self-paced basis (e.g., Athabasca University - Canada’s Open University). 
Grant \& Spencer The Personalized System of Instruction: Review and applications to distance education

\section{Use of Proctors}

PSI courses make use of course staff called proctors or tutors to help students learn the material, administer unit quizzes, provide feedback regarding unit quiz performance, and conduct certain administrative tasks such as maintaining student records. PSI proctors can be external or internal proctors. External proctors are former students who receive academic credit for proctoring a course. Internal proctors are students enrolled in the course, who have passed early units in the course, and are now assisting students with the units they have already mastered. Some PSI courses also make use of professional tutors or proctors who are paid for their work. In an online environment, tutors can have homepages that provide contact information and autobiographical sketches for students (e.g., Psychology Tutor: Dr. Alan LeBoeuf, 2002; Psychology Tutor: Rebecca Heartt, 2002).

\section{Lectures and Demonstrations as Motivational Devices}

With PSI's emphasis on the written word, lectures tend to be de-emphasized. However, the founders of PSI also felt there was a place for lectures in order to stimulate the students' interest in the subject matter, so occasional lectures were initially included as a feature of a PSI course. Unlike the other components of PSI, lectures have not been demonstrated to be effective in boosting student academic performance (e.g., Brothen and Wambach, 1998; Johnson and Ruskin, 1977), and should be considered as an optional feature of the method, at best, that might be reserved for those rare spellbinding lecturers. Note that PSI is an evolving data-driven system, not an ideological model that asserts . priori definitions about what represents good instruction. The data dissuading teachers from lecturing illustrate that PSI is a model that is subject to alterations in accordance with new data.

\section{A Brief History of PSI}

\section{Growth of PSI From 1968 to 1980}

A useful starting point in the history of PSI is Dubin and Taveggia's (1968) book The TeachingLearning Paradox: A Comparative Analysis of College Teaching Methods in which the authors analyzed the results of 74 empirical comparison studies of higher education teaching methods conducted from 1924 to 1965 . The methods reviewed included face-to-face techniques as the lecture, group-discussion, tutorials, as well as independent study in which students take primary responsibility for their own learning. Dubin and Taveggia found no consistent differences in the results attained by any of the methods studied. They concluded: "These data demonstrate clearly and unequivocally that there is no measurable difference among truly distinctive methods of college instruction when evaluated by student performance on final examinations”(p. 35).

Dubin and Taveggia's milestone work had several important implications, one of which was empirical support for programs of independent study and distance education. The finding that students did equally well in an independent study format, in which they managed their own learning without a classroom instructor, gave considerable credence to alternative methods of instruction in which students work largely on their own, as in independent study and distance education courses. If teaching methods do not matter, then why not allow students to work on their own in independent-study or distance education formats, which provide more convenience to students? Why not use teaching methods that reduce the costs of instruction without any 
reduction in student achievement? These questions continue to be important and relevant with respect to most teaching methods.

The same year that Dubin and Taveggia published their findings, Keller (1968) introduced PSI, outlined its basic features, and described the operation of the system in an actual classroom. Keller's initial work led to a boom in PSI research during the 1970s that clearly demonstrated the superiority of PSI over conventional methods of instruction (Johnson and Ruskin, 1977; Kulik, Kulik, and Cohen, 1979). This work showed that: (a) PSI students learned more than students taught using conventional (i.e., lecture, lecture-discussion) methods, and that (b) students rated PSI courses more favorably than conventional courses (Buskist, Cush, and DeGrandpre, 1991; Johnson and Ruskin, 1977; Kulik et al., 1979). With respect to the latter point, Kulik et al. (1979) concluded: "Differences in student ratings of PSI and control classes are also pronounced. Students rate PSI classes as more enjoyable, more demanding, and higher in overall quality and contribution to student learning than conventional classes”(p. 317).

The finding that PSI is more effective than standard methods of university instruction represents an important hallmark in the history of higher education, especially when considered in relation to Dubin and Taveggia's earlier findings. Confronted with the new data showing the benefits of PSI, Taveggia (1976) wrote: "The major conclusion suggested by this summary of research is that, when evaluated by average student performance on course content examinations, the Personalized System of Instruction has proven superior to the conventional teaching methods with which it has been compared" (p. 1032). Taveggia's conclusion was especially important because it came from an individual well known for maintaining that no teaching method is superior to any other.

\section{PSI From 1980 Onward}

During the early 1980s, interest in PSI, as reflected in publication activity in professional journals and presentations at conferences, diminished (Buskist et al., 1991; Lamal, 1984; Polson, 2000a). In its heyday, advocates of PSI had hoped that it would eventually either replace the lecture method, or at least firmly establish itself as a teaching method used by a substantial minority of college and university instructors. In a survey of past users of PSI, Lloyd and Lloyd (1986) found that of 43 previous users of PSI, 23 continued to use the system.

Many reasons for the waning of interest in PSI have been advanced. These include: a) The recalcitrance of the educational establishment to change (Buskist et al., 1991; Cracolice and Roth, 1996; Lloyd and Lloyd, 1986; Sherman, 1992); b) implementations of ineffective teaching methods people called "PSI" that did not meet the proper criteria for PSI (Buskist et al., 1991; Gallup and Allen, 2002; Sherman, 1992); c) the time demanded in setting up and maintaining a PSI course (Buskist et al. 1991; Cracolice and Roth, 1996; Lloyd and Lloyd, 1986); d) misunderstandings of the nature of PSI in the academic literature (Buskist, et al. 1991; Gallup and Allen, 2002; Reboy and Semb, 1991); and e) outright prohibitions of PSI courses (Sherman, 1992). Another factor that eroded interest in PSI was that during the 1980s there was a shift in emphasis in academics from teaching to research (Boyer, 1990), which worked against a timeintensive teaching method like PSI.

Perhaps the most important factor that has mitigated the popularity of PSI, is the absence of a focus on empirical evidence of student achievement and student satisfaction as core values and key criteria for selecting instructional methods. PSI's greatest strength is the evidence showing that when students engage in PSI courses, they learn more and tend to like them more than 
Grant \& Spencer The Personalized System of Instruction: Review and applications to distance education

traditional courses. In addressing the role of data in influencing educational decision-making, Carnine (2000), relying on Porter's (1996) analysis, distinguishes between immature and mature professions:

. . . immature profession is characterized by expertise based on the subjective judgments of the individual professional, trust based on personal contact rather than quantification, and autonomy allowed by expertise and trust, which staves off standardized procedures based on research findings that use control groups. A mature profession, by contrast, is characterized by a shift from judgments of individual experts to judgments constrained by quantified data that can be inspected by a broad audience, less emphasis on personal trust and more on objectivity, and a greater role for standardized measures and procedures informed by scientific investigations that use control groups.

Not surprisingly, Carnine (2000) concludes that education does not meet the criteria for a mature profession. The history of PSI certainly supports this conclusion in the realm of higher education: Although the experimental data support PSI, the typical criteria for educational decision-making are those identified with an immature profession. Indeed, empirical evidence that supports PSI is entirely absent in discussions of how to teach. For example, the Carnegie Foundation's bibliography of the Scholarship of Teaching and Learning (Hutchings and Bjork, 1999) contains many thought-provoking books and articles, but few empirical studies and reviews of empirical research pertaining to teaching effectiveness. To be sure, the questions that confront a teacher in deciding how to teach are not solely empirical questions answered in comparison studies, but to be equally sure, decisions of teaching methods should not be made without some attention to the rich empirical literature of teaching effectiveness, a key part of which is the PSI literature.

The decline in use of PSI over time should not be constructed as an abject failure for the system. Although the use of PSI lessened since the period of peak use in the 1970s, many educators steadily continued to use and conduct research in PSI. Lloyd and Lloyd (1986) called attention to PSI users who ceased using the method, but their survey data showed that over half of the early users of PSI continued to use the method. During the 1990s work in PSI has continued. A PSI webpage ( $h$ ttp://ww2.lafayette.edu/ allanr/psi.html ) identifies many current users of the method, and provides helpful articles and papers for new and continuing users (Allan and Gallup, 2002). An online, Web-based tutorial provides information about the basic elements of PSI (Polson, 2000a). In publications from 1990 onward, PSI also continues to extend its strong foundation of research supporting the method (e.g., Austin, 2000; Brothen, 1996; Brothen and Bazzarre, 1998; Brothen and Wambach, 1998; 2001; Buzhardt and Semb, 2002; Cregger and Metzler, 1992; Hambleton, Foster, and Richardson, 1998; Herzberg, 2001; Pear and Crone-Todd, 1999; Price, 1999; Roberts, Suderman, Suderman, and Semb, 1990; Steel, Brothen, and Wambach, 2001).

\section{Misconceptions about PSI}

There are many misconceptions about PSI, perhaps because many educators have only a casual familiarity with the method. Among the most troublesome misconceptions are that PSI is not appropriate to teaching higher-order skills and abilities, and that PSI is somehow tied to a particular theory of learning. 


\section{Higher-Order Objectives in PSI Courses}

Some have maintained that PSI is not suited to teaching higher-order skills such as those involved in concept learning and critical thinking (e.g., Meek, 1977). However, as an instructional system, PSI is a set of practices that is independent of instructional content and instructional objectives (Reboy and Semb, 1991). PSI only demands instructional content that is amenable to observable assessment in the form of unit quiz scores or some other type of performance (e.g., essay-writing, first-aid skills demonstrations, lifesaving demonstration, debating exhibition, poetry writing, experimental design and execution) that may be assessed and graded according to clear and fair criteria. PSI is not well suited to teaching skills like reaching a nirvana state in which the phenomenon is entirely internal without any measurable criteria, although it is not clear that there are any definable teaching methods well suited for teaching this kind of performance.

Teaching higher-level objectives in college and university courses is a challenge for all educators, including users of PSI. However, advocates of PSI have had a long-standing concern with this issue. Semb and Spencer (1976) interviewed 17 university instructors who used the lecturediscussion method. Although the instructors estimated that 33 percent of the content taught in their classes required more than memorization of facts, an empirical analysis of the tests in these courses revealed that less than 10 percent of the content required more than factual recall. These early data showed that any criticisms of PSI in failing to teach higher-order skills were not specifically applicable to PSI, but instead were broadly applicable to university courses in general. Caldwell (1985) stresses that instructors who wish to teach higher-order objectives must explicitly define those objectives during course development and not simply teach textbook content.

Those favorably disposed to the PSI approach have explored instruction in higher-order objectives on several fronts. This includes research in learning abstract concepts and principles (Grant, 1986), the design of entire textbooks to promote conceptual learning and abstract thinking (Grant and Evans, 1994; Miller, 1997; Miller and Weaver, 1976), the empirical validation of methods to teach complex concepts (Grant, 2002; Grant, in press), and systems for identifying and implementing higher-order objectives (Pear, 2002). In a review of the literature of PSI in teaching higher-order skills, Reboy and Semb (1991) documented that PSI has been used in many courses such as critical thinking (Ross and Semb, 1981) that require that students learn higherorder objectives. They also showed that students who take PSI, and similarly designed courses, improve their higher-order cognitive abilities. PSI achieved many of its initial successes in physics, engineering, and the sciences (Kulik, Kulik, and Carmichael, 1974), where students must generally engage in abstract thinking to apply principles to solve novel problems. More recently, researchers associated with the Computer-Aided Personalized System of Instruction (CAPSI) project have studied and developed careful procedures for reliably identifying higher-level objectives using Bloom's taxonomy (Bloom, 1956), and incorporating them into PSI courses (Crone-Todd and Pear, 2001; Crone-Todd, Pear, and Read, 2000; Pear, Crone-Todd, Wirth, and Simister, 2001). All these considerations show that PSI users have been major contributors to the literature of teaching higher-order objectives.

\section{PSI Accommodates Diverse Educational Perspectives}

Although PSI was originally designed based on behavioral principles (Keller and Sherman, 1974; Sherman, 1982), PSI is compatible with a wide range of philosophical and theoretical viewpoints with respect to learning and instruction (Coldeway and Spencer, 1982). All of the individual features of PSI have appeared in a variety of theoretical historical contexts. The unit-mastery 
Grant \& Spencer The Personalized System of Instruction: Review and applications to distance education

criterion, for example, is simply the idea of learning until standards are achieved, a concept implicit even in writings as early as Aristotle's Poetics. Proctors or tutors, often PSI-like peer tutors, have assisted students for centuries to achieve practical educational outcomes (Wagner, 1982). Likewise, PSI's use of the written word and the concept of separating complex material into manageable portions are scarcely modern innovations tied to a psychological or philosophical perspective.

By including discovery learning experiences, PSI can incorporate content that is consistent with constructivist approach to education. Pear and Crone-Todd (2002) described how a PSI course can embrace social constructivist principles. Consistent with the constructivist approach, PSI is a learner-centered system that puts the student in an active and focal role (Buskist et al., 1991; Coldeway and Spencer, 1982). As Coldeway and Spencer (1982) maintained, PSI is helpful to educators because it provides a sound instructional baseline upon which the instructor can add content, tailor student assignments, and otherwise structure the course according to their own philosophy of education. Founders of PSI encouraged the development of PSI in different academic fields, permitting Sherman (1982) to surmise that PSI had been used to teach all major academic disciplines. This track record of diversity is compelling evidence that PSI can accommodate a wide range of subject matters, instructor styles, and educational philosophies.

\section{PSI Applied to Distance Instruction}

PSI may be broadly regarded as a universal system of instruction that is applicable to diverse teaching environments (Brothen, Wambach, and Hansen, 2002; Coldeway and Spencer, 1982). The key features of PSI are apportioning written material into manageable units, requiring mastery, using proctors, moving at the individual student's pace, and applying sound instructional principles generally characteristic of well-designed instruction. PSI's universality and flexibility are highlighted by its use in diverse disciplines, such as its application in elementary schools (e.g., Klishis, Hursh, and Klishis, 1980; Werner and Bono, 1977); and other instructional programs including bank training (Tosti and Jackson, 1980); military training (McMichael, Brock, and DeLong, 1976); and teaching self-help skills to the underprivileged (Fawcett, Mathews, Fletcher, Morrow, and Stokes, 1976).

As a domain in which to apply the quasi-universal principles of PSI, distance education is a promising field (Coldeway and Spencer, 1982; Kinsner and Pear, 1988; Lauzon and Moore, 1989; Pear and Kinsner, 1988; Schmitt, 1998). Due to the nature of PSI as an integrated package, with its emphasis on the written word, flexibility in relation to distance learners and adoption of computer and telecommunications technologies, PSI is especially applicable to distance education and the emerging scholarship of teaching.

\section{PSI as an Integrated Foundation for Distance Courses}

As an instructional package, PSI provides distance instructors with a set of effective practices that can serve as a starting point for developing distance courses. PSI serves as a flexible blueprint for distance course design and delivery, focuses the role of the tutor, and provides students with a degree of structure that facilitates independent learning (Coldeway and Spencer, 1982). In the absence of a system like PSI, many instructors are apt to fall back on merely electrifying the lecture method as an initial foray into distance learning, which represents an awkward application of an ineffective classroom model to distance delivery (Clark, 1983). After initial experiences with PSI, distance instructors can modify the components of PSI to suit their particular 
requirements due to PSI's adaptive-ness and flexibility. There is also a rich PSI literature to guide instructors, including a PSI handbook (Keller and Sherman, 1974), a review of all aspects of PSI (Johnson and Ruskin, 1977), and online, distance-learning examples of PSI courses (ComputerAided Personalized System of Instruction, 2002; Grant, 2002a; 2002b).

\section{The Prominence of the Written Word in PSI and Distance Instruction}

Generally, PSI and distance education share an emphasis on the written word as a medium for teaching and learning, effectively bringing distance instruction into greater concordance with PSI than with traditional lecture-based classroom practices. Partly out of necessity, many distance educators have rethought education from the ground up, and this openness to nontraditional practices has resulted in a relatively greater reliance on the written word.

One of the historical impediments to the adoption of PSI in the classroom has been the extra work required for the development of PSI study guides and other written course materials (Buskist et al., 1991; Cracolice and Roth, 1996; Lloyd and Lloyd, 1986). However, distance learning instructors are generally compelled to develop such ancillary study materials as study guides and student manuals no matter which instructional method they select, thereby reducing or eliminating the relative disparity of work required to implement PSI in distance learning. Early in the development of the field of distance education, such pioneering institutions like the Open University in Britain and Athabasca University in Canada, established the precedent of developing course packages that included written study guides for students that specified learning objectives and were divided into manageable units. As a result, much of contemporary distance instruction makes use of unit-by-unit PSI-like study guides.

\section{PSI's Flexibility for Distance Learners}

PSI provides considerable flexibility for students just as it does for instructors (Coldeway and Spencer, 1982). Students often turn to distance instruction for reasons of flexibility, and the four main features of PSI: emphasis on the written word, self-pacing, mastery criteria, and use of tutors/proctors provide for this.

Emphasis on the written word in PSI makes it possible for students to do their course work at virtually any physical location at which they can read. In this respect, PSI students are freed from geographic barriers to learning due to the nature of the written word, which, in turn, makes learning more flexible.

Most distance learners have work and family interests apart from their distance courses, and PSI's self-pacing feature permits students to adapt their course work to other activities in their lives, rather than the reverse. In a PSI course, students take an active role in managing their own learning and scheduling their own assignments, providing them with the opportunity to function as independent learners, albeit with the support of PSI materials, tutors/ proctors, and other structured elements of a PSI course.

The mastery-learning feature of PSI courses is also helpful to distance learners who must fulfill multiple responsibilities. If a PSI learner fails to budget enough time to pass a quiz or other assignment, there is an educational safety net in the form of the opportunity to retake the quiz or redo the assignment. 
Grant \& Spencer The Personalized System of Instruction: Review and applications to distance education

Proctors or tutors in a PSI course serve to humanize the course for distance learners, who often feel isolated and alone in their studies. These course personnel are available to adapt the course content to the requirements of individual students, provide inspiration and emotional support, go over troublesome points, set up a study schedule, suggest further readings, etc.

The self-paced and mastery-learning features of PSI also have considerable appeal to disabled learners (Brothen et al., 2002). Many of these students are drawn to distance education as a means of overcoming physical barriers; the addition of the flexibility of PSI to distance learning further accommodates students with disabilities.

\section{Technology in PSI and Distance Education}

Both PSI and distance education have been facilitated by the developments in computer and telecommunications technology, and have generally embraced technology as a means of both reaching students and improving instructional effectiveness. For example, the use of computerbased assessment in PSI classrooms and in distance-learning courses (Barnes, Swehosky, and Laguna-Castillo, 1988; Buzhardt and Semb, 2002; Crosbie and Kelly, 1993; Grant, 2002a, 2002b; Pear and Kinsner, 1988; Pear and Crone-Todd, 1999) has automated the process of quiz administration and quiz record keeping. PSI courses and well designed distance learning courses require instructors to keep detailed records of student quizzes and assignments in order to track student progress (Keller and Sherman, 1974; Pear, 2002). Computer-based versions of PSI all substantially ease the burden of record-keeping and other logistical requirements for a PSI instructor, in addition to providing students with the increased flexibility of taking unit quizzes 24 hours per day, 7 days per week. In Grant's (2002a, 2002b) distance learning courses, for example, course tutors once administered all unit quizzes over the telephone in a variant of Ferster's (1968) oral interview technique. This required that course tutors spend considerable time in the mechanical process of administering the quiz and recording students' answers. However, once online quizzes were introduced in 1996, course tutors were freed from these routine clerical tasks and were able to devote a greater proportion of their time to discussing course content with students, correcting student misconceptions, providing students with help with procrastination problems, etc. Currently, approximately 90 percent of students enrolled in the courses take quizzes online, although the option to do the unit quizzes over the telephone remains for students who do not have access to an Internet-enabled computer.

Both PSI and distance education courses share the benefits of extending the traditional medium of the printed word to computer-based and online self-instructional resources (Coldeway and Spencer, 1982). Research showing the effectiveness of computer-based learning over traditional print-based alternatives (Bangert-Drowns, Kulik, and Kulik, 1985; Kulik, 1994; Kulik, Kulik, and Shwalb, 1986) indicates that print-based study guide materials can, and should, be transformed into interactive computer-based self-instructional resources. Computer-based instruction makes for a more active learning experience by allowing students to receive ongoing feedback regarding their knowledge, comprehension, application, analysis, synthesis, and evaluation of course content, as well as providing a more convenient and rapid interface to knowledge databases. For example, students engaged in online PSI courses can make use of interactive computer-based tutorials and exercises (Grant, in press; Grant, 1996; Polson, 2000a; 2000b, Parsons and Polson, 2000; Randall and Grant, 2000), an interactive online glossary of terms (Polson, LeBoeuf, Schwartzberg, and Grant, 2002), and a History of Psychology Timeline (History of Psychology Visual Timeline, 2002). Computer-based and online instruction serve to make PSI even more effective, student-friendly, and applicable to distance learning. 


\section{The Model of the Teacher-Researcher in PSI and in Distance Education}

A third common aspect of PSI applied to distance education is its potential contribution to a scholarship of teaching and learning capable of aligning the two areas, allowing distance educators to draw upon the rich PSI literature as a source of teaching applications and research ideas, while allowing PSI teacher-researchers to extend their work into distance instruction. Since its inception, PSI users have often been teacher/ researchers who have critically examined their teaching practices, often from an empirical standpoint, and have disseminated their findings in professional forums. This model of teacher/ researcher became popular in PSI, partly because those who collected data about the method found results that favored the method, consistent with the empirical reviews discussed earlier.

The model of teacher/ researcher is also consistent with Boyer's (1990) landmark call for a reformulation of university scholarship to reestablish teaching as a valued academic activity. Boyer found that many university teachers were generally dissatisfied with the traditional incentive systems that rewarded disciplinary research at the expense of teaching, one of the factors that led to the decline of PSI and other innovative forms of effective instruction. To address this problem, Boyer called for an expanded definition of scholarly publications to include a broader range of writing. Properly implemented, this expanded definition of academic writing could encompass PSI and distance education study guides that have not been traditionally considered publications for purposes of tenure review and promotion, despite the considerable scholarly effort that goes into developing these materials. The expanded definition of academic writing could also include teacher/ researcher reports of course delivery activities, including empirical studies of the effects of variations on PSI formats and study guide materials.

A prototypical example of a teacher/ researcher program that combines PSI and distance education is the Computer-Aided Personalized System of Instruction (CAPSI) program (2002), described earlier. The materials at the site extend PSI research to distance education. CAPSI represents a scholarship of teaching that merges the empirical foundations of PSI with distance instruction, and promotes leading-edge research in areas such as teaching higher-order objectives. The site includes interesting position papers, a list of publications, and discussions of research in progress.

\section{Summary}

Measured according to the criteria examined earlier, higher education has yet to become a mature data-driven field. In the absence of data as a guide, educational trends and fashions are often driven by charismatic authority figures and opinion leaders who come in and out of vogue. Educational theories and practices become popular for several years, only to wane in importance and be replaced by new trends that are similarly as unsupported by data as their predecessors. In the midst of this ebb and flow, predicting future trends in educational practices is difficult because the practices typically do not have a solid foundation of empirical support.

PSI, nonetheless, continues to offer the prospect of more effective instruction. Recent developments in higher education and in technology have provided the basis, at least in principle, for growth of PSI courses in distance education. Colleges and universities seem to be inching toward greater attention to teaching, and the scholarship of teaching promises to elevate the profile and status of instructional research, which should assist PSI users who have a strong commitment to teaching. Distance education continues to grow and provide a new platform for the teaching/ learning process that requires consideration of alternative models like PSI. Research 
in PSI continues to break new ground in exploring the learning processes involved in achieving higher-order educational objectives. Educational technology makes PSI easier to implement and operate than ever before and expands the range of self-instructional learning resources available to distance learners. All these considerations provide grounds for optimism about the future of PSI, but until education matures into a data-based field, PSI may lay dormant in much the same way as Mendel's original discoveries in genetics lay unheeded for decades before they provided a foundation for modern biological science. Whatever the ultimate future of the system may be, PSI now provides distance educators with a teaching/ learning method that will allow students to achieve more and to like their courses better.

\section{References}

Allan, R., and Gallup, H. (2002). The PSI homepage. Lafayette College website. Retrieved November 12, 2002 from: http://ww2.lafayette.edu/ allanr/psi.html

Austin, J. L. (2000). Behavioral approaches to college teaching. In J. Austin and J. E. Carr (Eds.) Handbook of applied behavior analysis (p. 449-472). Reno, NV.: Context Press.

Bangert-Drowns, R. L., Kulik, J. A., and Kulik, C-L. C. (1985). Effectiveness of computer-based education in secondary schools. Journal of Computer-Based Instruction, 12, 59 - 68.

Barnes, W., Swehosky, F. J., and Laguna-Castillo, M. (1988). Using an instructional LAN to teach a statistics course. T.H.E. Journal, 16, $80-84$.

Bloom, B. S. (1956). Taxonomy of Educational Objectives: Cognitive and affective domains. New York: David McKay.

Boyer, E. L. (1990). Scholarship Reconsidered: Priorities of the professoriate. Princeton, NJ.: Carnegie Foundation for the Advancement of Teaching.

Brothen, T. (1996). Comparison of non-performers and high performers in a computer-assisted mastery learning course for developmental students. Research and Teaching in Developmental Education, 13, 69 - 73.

Brothen, T., and Bazzarre, M. E. (1998). An intervention to remediate developmental students' procrastination in a computer-based PSI course. The Learning Assistance Review, 3, 5 11.

Brothen, T., and Wambach, C. (1998). An evaluation of lectures in a computer-based, PSI introductory psychology course. Journal of Educational Technology Systems, 27, 147 155.

Brothen, T., and Wambach, C. (2001). Effective student use of computerized quizzes. Teaching of Psychology, 28, $292-294$.

Brothen, T., Wambach, C., and Hansen, G. (2002). Accommodating students with disabilities: PSI as an example of universal instructional design. Teaching of Psychology, 29, 239 240. 
Grant \& Spencer The Personalized System of Instruction: Review and applications to distance education

Buskist, W., Cush, D., and DeGrandpre, R. J. (1991). The life and times of PSI. Journal of Behavioral Education, 1, 215 - 234.

Buzhardt, J., and Semb, G. B. (2002). Item-by-item versus end-of-test feedback in a computerbased PSI course. Journal of Behavioral Education, 11, 89 - 104.

Caldwell, E. C. (1985). Dangers of PSI. Teaching of Psychology, 12, 9 - 12.

Carnine, D. (2000). Why education experts resist effective practices (and what it would take to make education more like medicine). Thomas B. Fordham Foundation website. Retrieved November 12, 2002 from: www.edexcellence.net/library/carnine.html

Clark, R. E. (1983). Reconsidering research on learning from media. Review of Educational Research, 53, 445 - 449.

Coldeway, D. O., and Spencer, R. E. (1982). Keller's Personalized System of Instruction: The search for a basic distance learning paradigm. Distance Education, 3, 51 - 71.

Computer-Aided Personalized System of Instruction. (2002). University of Manitoba website. Retrieved October 23, 2002 from: http://home.cc.umanitoba.ca/ capsi/index.html

Cracolice, M. S., and Roth, S. M. (1996). Keller’s “Old” Personalized System of Instruction: A "New" Solution for Today's College Chemistry Students. The Chemical Educator. Article 10.1007/s00897960004a. Retrieved November 12, 2002, from: http://link.springer-ny.com/link/service/journals/00897/tocs/t6001001.htm

Cregger, R., and Metzler, M. (1992). PSI for a college physical education basic instructional program. Educational Technology, 32, 51 - 56.

Crone-Todd, D. E., and Pear, J. J. (2001). Application of Bloom's Taxonomy to PSI. Behavior Analyst Today, 3, $204-210$.

Crone-Todd, D. E., Pear, J. J., and Read, C. N. (2000). Operational definitions of higher-order thinking objectives at the post-secondary level. Academic Exchange Quarterly, 4, 99 106.

Crosbie, J., and Kelly, G. (1993). A computer-based Personalized System of Instruction course in applied behavior analysis. Behavior Research Methods, Instruments, and Computers, 25, $366-270$.

Dubin, R., and Taveggia, T. C. (1968). The Teaching-Learning Paradox: A comparative analysis of college teaching methods. Eugene OR.: Center for the Advanced Study of Educational Administration.

Fawcett, S. B., Mathews, R. M., Fletcher, R. K., Morrow, R., and Stokes, T. F. (1976). Personalized Instruction in the Community: Teaching helping skills to low-income neighborhood residents. Journal of Personalized Instruction, 1, 86 - 90. 
Ferster, C. B. (1968). Individualized instruction in a large introductory psychology course. The Psychological Record, 18, 512 - 532.

Gallup, H. F., and Allan, R. W. (2002). Concerns with some recent criticisms of the Personalized System of Instruction (PSI). Lafayette College website. Retrieved November 12, 2002 from: http://ww2.lafayette.edu/\%7Eallanr/concerns.html

Grant, L. (1986). Categorizing and concept learning. In H. Reese and L. J. Parrott (Eds.) Behavior Science: Philosophical, methodological, and empirical advances (p. 139-162). Hillsdale, NJ.: Lawrence Erlbaum.

Grant, L. (1996). Positive Reinforcement: A self-instructional exercise. Athabasca University Canada's Open University, website. Retrieved November 12, 2002 from:

http://server.bmod.athabascau.ca/html/prtut/reinpair.htm

Grant, L, K. (in press). Teaching positive reinforcement on the Internet. Teaching of Psychology.

Grant, L. K. (2002a). Psychology 375 (History of Psychology): Student Manual. Athabasca University - Canada's Open University website. Retrieved November 12, 2002 from: http://psych.athabascau.ca/html/Psych375/Manual/

Grant, L. K. (2002b). Psychology 387 (Learning): Student Manual. Athabasca University Canada's Open University website. Retrieved November 12, 2002 from: http://psych.athabascau.ca/html/Psych387/387/manual.shtml

Grant, L. K. (2002). Word diagrams in teaching classical conditioning. The Psychological Record, 52, 129 - 138.

Grant, L., and Evans, A. (1994). Principles of behavior analysis. New York: Harper Collins.

Hambleton, I. R., Foster, W. H., and Richardson, J. T. E. (1998). Improving student learning using the Personalised System of Instruction. Higher Education, 35, 187 - 203.

Herzberg, P. (2001). The Keller Plan: 25 years of personal experience. McMaster University website. Retrieved Nov. 8, 2002 from the: http://www.mcmaster.ca/learning/posped/Jan2001/herzberg101.html

History of Psychology Visual Timeline. (2002). Athabasca University - Canada's Open University, Centre for Psychology website. Retrieved November 9, 2002 from: http://psych.athabascau.ca/html/History/

Hutchings, P., and Bjork, C. (1999). An annotated bibliography of the scholarship of teaching and learning in higher education. Carnegie Foundation for the Advancement of Teaching website. Retrieved November 12, 2002 from:

http://www.carnegiefoundation.org/CASTL/highered/bibliography.htm

Johnson, K. R., and Ruskin, R. S. (1977). Behavioral Instruction: An evaluative review. Washington, DC.: American Psychological Association. 
Keller, F. S. (1968). “Good-bye, teacher ...” Journal of Applied Behavior Analysis, 1, 79 - 89.

Keller, F. S., and Sherman, J. G. (1974). The Keller Plan handbook. Menlo Park, CA.: W. A. Benjamin.

Kinsner, W., and Pear, J. J. (1988). Computer-aided Personalized System of Instruction for the virtual classroom. Canadian Journal of Educational Communications, 17, 21 - 36.

Klishis, M. J., Hursh, D. C., and Klishis, L. A. (1980). Individualized spelling: An application and evaluation of PSI in the elementary school. Journal of Personalized Instruction, 4, $148-156$.

Kulik, C-L.C., Kulik, J. A., and Shwalb, B. J. (1986). Effectiveness of computer-based adult education: A meta-analysis. Journal of Educational Computing Research, 2, 235 - 252.

Kulik, J. A. (1994). Meta-analytic studies of findings on computer-based instruction. In E. L. Baker and H. F. O’Neil (Eds.) Technology assessment in education and training. Hillsdale, NJ.: LEA Publishers.

Kulik, J. A., Kulik, C-L., and Carmichael, K. (1974). The Keller Plan in science teaching. Science, 183, $379-383$.

Kulik, J., Kulik, C. L. C., and Cohen, P. A. (1979). A meta-analysis of outcome studies of Keller's Personalized System of Instruction. American Psychologist, 34, 307 - 318.

Lamal, P. A. (1984). Interest in PSI across sixteen years. Teaching of Psychology, 11, 237 - 238.

Lauzon, A. C., and Moore, G. A. B. (1989). A fourth generation distance education system: Integrating computer-assisted learning and computer conferencing. The American Journal of Distance Education, 3, 38 - 49.

Lloyd, M. E., and Lloyd, K. E. (1986). Has Lightening Struck Twice? Use of PSI in college classrooms. Teaching of Psychology, 13, 149 - 151.

McFarland, B. (1976). An individualized course in elementary composition for the marginal student. In B. A. Green (Ed.) Personalized Instruction in Higher Education: Proceedings of the second national conference (p. 45-48). Washington, CD: Center for Personalized Instruction.

McMichael, J. S., Brock, J. F., and Delong, J. (1976). Job-relevant navy training and Keller’s Personalized System of Instruction: Reduced attrition. Journal of Personalized Instruction, 1, $41-44$.

Meek, R. L. (1977). The traditional in non-traditional learning methods. Journal of Personalized Instruction, 2, $114-119$.

Miller, L. K. (1997). Principles of everyday behavior analysis (3rd Ed.) Pacific Grove, CA.: Brooks/ Cole. 
Miller, L. K., and Weaver, H. (1976). A behavioral technology for producing concept formation in university students. Journal of Applied Behavior Analysis, 9, 289 - 300.

Mills, H. (1978). Using evaluation forms to help students achieve mastery. In J. G. Sherman, R. S. Ruskin, and R. M. Lazar (Eds.) Personalized instruction in education today (p. 147152). San Francisco: San Francisco Press.

Parsons, J. A., and Polson, D. A. (2000). Engelmann Module.Athabasca University - Canada's Open University, Psychology Centre website. Retrieved November 12, 2002 from: http://psych.athabascau.ca/html/387/OpenModules/Engelmann/

Pear. J. J. (2002). Teaching and researching higher-order thinking in a virtual environment. University of Manitoba website. Retrieved November 12, 2002 from: http://home.cc.umanitoba.ca/ capsi/capsipapers2.htm

Pear, J. J., and Crone-Todd, D. E. (2002). A social constructivist approach to computer-mediated instruction. Computers \& Education, 38, 221 - 231.

Pear, J. J., and Crone-Todd, D. E. (1999). Personalized System of Instruction in cyberspace. Journal of Applied Behavior Analysis, 32, 205 - 209.

Pear, J. J., Crone-Todd, D. E., Wirth, K., and Simister, H. (2001). Assessment of thinking level in students' answers. Academic Exchange Quarterly, 5(4), 94 - 98.

Pear, J. J., and Kinsner, W. (1988). Computer-Aided Personalized Instruction: An effective and economical method for short- and long-distance education. Machine-mediated Learning, 2, $213-237$.

Polson, D. (2000a). Fred S. Keller and the Personalized System of Instruction. Athabasca University - Canada's Open University, Centre for Psychology website. Retrieved November 12, 2002 from: http://psych.athabascau.ca/html/387/OpenModules/Keller/

Polson, D. (2002b). Precision teaching module. Athabasca University - Canada’s Open University, Centre for Psychology website. Retrieved November 12, 2002 from: http://psych.athabascau.ca/html/387/OpenModules/Lindsley/

Polson, D. A., Le Boeuf, A., Schwartzberg, S., and Grant, L. K. (2002). An online glossary of psychological terms. Athabasca University - Canada’s Open University Centre for Psychology website. Retrieved November 12, 2002 from: http://server.bmod.athabascau.ca/html/Glossary/glossary.shtml

Porter, T. M. (1996). Trust in Numbers: The pursuit of objectivity in science and public life. Princeton, NJ.: Princeton University Press.

Price, R. V. (1999). Designing a college Web-based course using a modified personalized system of instruction (PSI) model. TechTrends, 43, 23 - 28. 
Psychology Tutor: Dr. Alan LeBoeuf (2002). Athabasca University - Canada’s Open University, Centre for Psychology website. Retrieved November 8, 2002 from:

http://psych.athabascau.ca/html/Tutors/alanl.shtml

Psychology Tutor: Rebecca Heartt (2002). Athabasca University - Canada’s Open University, Centre for Psychology website. Retrieved November 8, 2002 from: http://psych.athabascau.ca/html/Tutors/rebeccah.shtml

Randall, S. N., and Grant, L. K. (2000). Athabasca University - Canada’s Open University, Centre for Psychology website. Introductory biological psychology tutorials. Retrieved November 12, 2002 from: http://server.bmod.athabascau.ca/html/Psych289/Biotutorials/

Reboy, L. M., and Semb, G. B. (1991). PSI and Critical Thinking: Compatibility or irreconcilable differences? Teaching of Psychology, 18, 212 - 215.

Roberts, M. S., Suderman, L., Suderman, R., and Semb, G. B. (1990). Reading ability as a performance indicator in a behaviorally based psychology course. Teaching of Psychology, 17, $173-175$.

Ross, G. A., and Semb, G. (1981). Philosophy can teach critical thinking skills. Teaching Philosophy, 4, 56 - 63.

Schmitt, D. R. (1998). The Introductory Class in Higher Education: Some old problems and new considerations. The Behavior Analyst, 21, 281 - 287.

Semb, G., and Spencer, R. (1976). Beyond the Level of Recall: An analysis of higher-order educational tasks in college and university instruction (p. 115-126). In L. E. Fraley and E. A. Vargas (Eds.) Behavior research and technology in higher education. Gainesville, FL.: University of Florida.

Sherman, J. G. (1982). The theory behind PSI. In J. G. Sherman, R. S. Ruskin, and G. B. Semb (Eds.) The Personalized System of Instruction: 48 seminal papers (p. 12-14), Lawrence, KS.: TRI Publications.

Sherman, J. G. (1992). Reflections on PSI: Good news and bad. Journal of Applied Behavior Analysis, 25, $59-64$.

Steel, P., Brothen, T., and Wambach, C. (2001). Procrastination and personality, performance, and mood. Personality and Individual Differences, 30, 95 - 106.

Taveggia, T. C. (1976). Personalized instruction: A summary of comparative research, 19671975. American Journal of Physics, 44, $1028-1033$.

Tosti, D., and Jackson, S. M. (1980). A personalized system of instruction in bank training. In J. G. Sherman, R. S. Ruskin, and G. B. Semb (Eds.) The Personalized System of Instruction: 48 seminal papers (p. 284-286). Lawrence, KS.: TRI Publications.

Wagner, L. (1982). Peer teaching: Historical perspectives. Westport CT.: Greenwood Press. 
Werner, T. J., and Bono, S. F. (1977). The application of PSI to a second grade classroom, or, the lone arranger rides again. Educational Technology, 17, 20 - 24. 